\title{
Early colonization pattern of maize (Zea mays L. Poales, Poaceae) roots by Herbaspirillum seropedicae (Burkholderiales, Oxalobacteraceae)
}

\author{
Rose A. Monteiro ${ }^{1}$, Maria A. Schmidt ${ }^{1}$, Valter A. de Baura ${ }^{1}$, Eduardo Balsanelli ${ }^{1}$, Roseli Wassem ${ }^{2}$, \\ Marshall G. Yates ${ }^{1}$, Marco A.F. Randi ${ }^{3}$, Fábio O. Pedrosa ${ }^{1}$ and Emanuel M. de Souza ${ }^{1}$ \\ ${ }^{I}$ Departamento de Bioquímica e Biologia Molecular, Universidade Federal do Paraná, Curitiba, PR, Brazil. \\ ${ }^{2}$ Departamento de Genética, Universidade Federal do Paraná, Curitiba, PR, Brazil. \\ ${ }^{3}$ Departamento de Biologia Celular, Universidade Federal do Paraná,Curitiba, PR, Brazil.
}

\begin{abstract}
The bacterium Herbaspirillum seropedicae is an endophytic diazotroph found in several plants, including economically important poaceous species. However, the mechanisms involved in the interaction between $\mathrm{H}$. seropedicae and these plants are not completely characterized. We investigated the attachment of Herbaspirillum to maize roots and the invasion of the roots by this bacterium using $H$. seropedicae strain SMR1 transformed with the suicide plasmid pUTKandsRed, which carries a mini-Tn5 transposon containing the gene for the Discosoma red fluorescent protein (Dsred) constitutively expressed together with the kanamycin resistance gene. Integration of the mini-Tn5 into the bacterial chromosome yielded the mutant $H$. seropedicae strain RAM4 which was capable of expressing Dsred and could be observed on and inside fresh maize root samples. Confocal microscopy of maize roots inoculated with $H$. seropedicae three days after germination showed that $H$. seropedicae cell were attached to the root surface 30 min after inoculation, were visible in the internal tissues after twenty-four hours and in the endodermis, the central cylinder and xylem after three days.
\end{abstract}

Key words: confocal microscopy, diazotroph, endophytic, Herbaspirillum seropedicae.

Received: November 14, 2007; Accepted: March 27, 2008.

Bacterial colonization of plant internal tissue has been described in many plant species. Although many plant-colonizing bacteria are phytopathogenic, the majority of such interactions are either neutral or beneficial to the host plant. The first studies on the interactions of diazotrophic bacteria with poaceous plants involved Azotobacter paspali isolated from the soil or from plant rhizospheres (Döbereiner, 1966) and later it was shown that nitrogenfixing Azospirillum brasilense colonized both the rhizosphere and the root interior of several forage grasses and cereals (Baldani et al., 1986a) of the family Poaceae. In the last decade, new nitrogen-fixing genera have been identified that colonize internal plant tissues, including members of the genera Acetobacter, Burkholderia, Herbaspirillum and Pseudomonas (Lodewyckx et al., 2002). These bacteria are capable of occupying the intercellular spaces and the vascular tissue of host plants and are referred to as endophytic bacteria (James, 2000). It has been shown that

Send correspondence to Rose Adele Monteiro. Departamento de Bioquímica e Biologia Molecular, Universidade Federal do Paraná, Rua Francisco H. dos Santos s/n, Caixa Postal 19046, Jardim das Américas, 81531-990 Curitiba, PR, Brazil. E-mail: rose.adele@ terra.com.br and roseadele@ufpr.br. the endophytic interaction can enhance plant growth, increase plant resistance to pathogens and specific xenobiotics (Reiter et al., 2002; Siciliano et al., 2001) and possibly transfer fixed nitrogen to the host (James and Olivares, 1998).

The endophytic nitrogen-fixing bacterium Herbaspirillum seropedicae (Burkholderiales, Oxalobacteraceae) associates not only with economically important poaceous plants such as maize, sugar cane and sorghum (Baldani et al., 1986b) but also agriculturally important tropical plants such as banana and pineapple (Cruz et al., 2001). This bacterium is known to colonize maize, rice, sorghum, sugar cane and wheat, first invading the intercellular spaces of the roots and then occupying the xylem vessels (James and Olivares, 1998; Roncato-Maccari et al., 2003) and the aerial parts of the plant involved (James et al., 2002; Roncato-Maccari et al., 2003). Although great numbers of $H$. seropedicae cells can be found in internal plant tissues, the mechanisms of infection and colonization are not completely understood, and a better understanding of these processes is needed to ensure that $H$. seropedicae and other endophytes can be the efficiently used as biofertilizers. 
Identifying and tracking endophytic bacteria within the host plant is a necessary step in understanding colonization mechanisms. Microscopy and tagging bacteria with reporter genes such as gus $A$ can be used to investigate colonization but these techniques can produce artifacts during sample preparation. However, such problems can be avoided by marking endophytic bacteria with genes that allow the expression of fluorescent proteins which provide a unique visual marker in fresh plant tissue samples and the application of confocal microscopy, a technique which allows visualization of bacteria in thick samples and is tolerant to the background autofluorescence which often occurs with plant tissue. Assmus et al. (1995) reported using a similar strategy involving fluorescently-labeled rRNA probes to detect $A$. brasilense in the rhizosphere of wheat.

During the study described in this paper, we used confocal microscopy of transverse sections of fresh maize (Zea mays L. Poales, Poaceae) roots to examine the progression of the early events of maize colonization by $H$. seropedicae strains expressing the coral-derived Discosoma red (DsRed) fluorescent protein (Matz et al., 1999), and to characterize the distribution and organizational patterns of the bacterial cells within the plant tissues.

We electro-transformed the spontaneous streptomycin-resistant (SmR) H. seropedicae strain SmR1 (Pedrosa et al., 1997) with the pUTKandsRed plasmid (TolkerNielsen et al., 2000) and obtained 45 kanamycin-resistant recombinants, which expressed DsRed and were able to grow on nitrate and had nitrogenase activity (12 nmol ethylene/min.mg protein) and growth rates (growth rate coefficient $\mu=0.28 \mathrm{~h}^{-1}$ ) comparable to the wild-type strain. For the study described in this paper, we used a DsRed tagged recombinant colony, colony number four, which was assigned the code RAM4, and which produced a reddish color on NFbHPN medium agar plates (Klassen et al., 1997) after 2-3 days incubation at $30{ }^{\circ} \mathrm{C}$.

Bacterial attachment studies were carried out using H. seropedicae strains SmR1 and RAM4, each of which were grown in shake-flask cultures in $125 \mathrm{~mL}$ flasks containing $25 \mathrm{~mL}$ of NFbHPN medium (Klassen et al., 1997) (pH 6.5) at $30^{\circ} \mathrm{C}$ for $16 \mathrm{~h}$ and an agitation rate of 120 revs $\min ^{-1}$. The control for artifactual entry of bacteria during root manipulation was Escherichia coli strain $\mathrm{CC} 118$ (Tolker-Nielsen et al., 2000) containing plasmid pUTKandsRed (E. coli CC118-DsRed), which had been grown in shake-flask cultures in $125 \mathrm{~mL}$ flasks containing $25 \mathrm{~mL}$ of LB media (pH 6.8) at $30^{\circ} \mathrm{C}$ for $16 \mathrm{~h}$ and an agitation rate of 120 revs $\mathrm{min}^{-1}$. For use in the experiments, the number of colony forming units (CFU) was determined using serial dilution and plate counts, and standardized using calibrated optical density curves (data not shown).Seeds of the maize cultivar BR-3133 (bought from Santa Helena Sementes Ltda, Brazil) were sanitized by washing in $70 \%$ ethanol for $1 \mathrm{~min}$, followed by shaking for $20 \mathrm{~min}$ at $30^{\circ} \mathrm{C}$ in sodium hypochlorite ( $2 \% \mathrm{w} / \mathrm{w}$ available chlorine) solu- tion supplemented with $0.02 \%(\mathrm{v} / \mathrm{v})$ Tween 20 (USB, USA) and then washing for $30 \mathrm{~min}$ by gently shaking in sterile distilled water, the washing being repeated five times (modified from Roncato-Maccari et al., 2003). The sanitized seeds were transferred to 96-well deep-well blocks (Greiner Bio-One, Austria), each well being $9 \mathrm{~mm} \mathrm{x}$ $9 \mathrm{~mm} \times 35 \mathrm{~mm}$, and containing $3 \mathrm{M}$ filter paper plus $2 \mathrm{~mL}$ of plant medium (Egener et al., 1999) and grown for three days at $25^{\circ} \mathrm{C}$ using a $12 \mathrm{~h}$ light period and 1250 lux illumination provided by white-type fluorescent tubes (Aqua Glo, Japan). After three days of growth, seedlings were incubated with $1 \mathrm{~mL}$ of cell suspension containing $6 \times 10^{9} \mathrm{CFU}$ $\mathrm{mL}^{-1}$ of H. seropedicae strain SmR1 or RAM4 or the E. coli control. After $15 \mathrm{~min}$ of incubation at $30{ }^{\circ} \mathrm{C}$, roots were washed twice in sterile $\mathrm{NaCl} 0.9 \%$, cut, weighed and vortexed for $20 \mathrm{~s}$ in $1 \mathrm{~mL}$ of $\mathrm{NaCl} 0.9 \%$. The supernatant was used to determine the number of bacteria attached by plate counting. The diluted extracts were plated on solid NFbHPN medium (Klassen et al., 1997). After 24-48 h incubation at $30{ }^{\circ} \mathrm{C}$, the number of colony forming units (CFU) was determined, further samples being taken every $15 \mathrm{~min}$ for one hour. Three replicated experiments were performed, with the roots from three plants being analyzed in each experiment.

For internal colonization studies, three-day old plantlets were inoculated with $6 \times 10^{9} \mathrm{CFU} \mathrm{mL}^{-1}$ for $30 \mathrm{~min}$ and were then transferred to sterile filter paper moistened with sterile plant medium (Egener et al., 1999) where they remained until $96 \mathrm{~h}$ after inoculation, after which the roots were surface sterilized as described by Roncato-Maccari et al. (2003), triturated in saline and the endophytic bacterial population determined on NFbHPN medium (Klassen et al., 1997). Confocal microscopy using a BioRad Confocal Radiance 2100-Eclipse E800 Nikon microscope (BioRad, USA) was used to examine maize roots, which were uninoculated or which had had been exposed to single-strain cultures of $H$. seropedicae strain RAM4 or the E. coli CC118-DsRed control. The bacteria were detected by exciting the DsRed protein with a helium-neon laser (BioRad, USA) with an excitation wavelength of $\lambda=543 \mathrm{~nm}$ in conjunction with an emission LP 560 filter (Nikon, Japan). For these experiments, maize roots were exposed to bacteria as described above, and then washed three times in water and transverse cross sections, approximately $25 \mu \mathrm{m}$ thick, were hand cut about $3 \mathrm{~cm}$ from the root tip, mounted on a microscope slide, and examined immediately. Three independent experiments were performed, and roots from three plants were analyzed for each data.

In the bacterial attachment studies, after 15 min incubation we recovered approximately $7 \times 10^{5} \mathrm{CFU} \mathrm{g}^{-1}$ of root tissue, on a fresh weight basis (fwb), for both strain SmR1 and RAM4. The number of CFU attached reaching a maximum of $1.5 \times 10^{7} \mathrm{~g}^{-1}$ of root tissue (fwb) after one hour of incubation, indicating that the capacity of strain RAM4 to attach to maize roots was similar to that of the SmR1 parent 
strain. For the internal colonization studies, on the fourth day after inoculation of the plantlets, we recovered approximately $6 \times 10^{6} \mathrm{CFU} \mathrm{g}^{-1}$ of root tissue (fwb) for both strain SmR1 and RAM4, indicating that strain RAM4 was not impaired in its capacity to colonize maize.

Using confocal microscope, $H$. seropedicae strain RAM4 showed bright red fluorescence and were visually distinct from the diffuse fluorescent background of the contour of the plant cells. After thirty minutes, the root surface showed dense agglomerates of strain RAM4, with the highest density of bacteria occurring at the intercellular spaces and, especially, at the emergence of root hairs, these points being probable routes used by the bacteria to invade the plant tissue. The early accumulation of bacteria at these points suggests that strain RAM4 was rapidly attracted, and apparently firmly attached, to discontinuities in the epidermis (Figure 1). Although a large number of bacteria were found attached to the surface after thirty minutes, there was no evidence of internal colonization. Incubation of the roots with strain RAM4 for $1 \mathrm{~h}$ produced essentially the same results, with an apparently higher number of cells attached. The preference of $H$. seropedicae strain RAM4 for the intercellular regions and lateral root emerging zones is probably related to a higher concentration of carbon sources at these points (Bennett and Lynch, 1981). Our finding agrees with studies that indicate that the lateral root emergence points are highly susceptible to disruption (Agarwhal and Sende, 1987). No agglomerates of E. coli CC118-dsRed was observed attached to the root surface
(Figure 1) and no internal colonization was found, strongly indicating that the presence of fluorescent $H$. seropedicae in the maize root tissues represents true internal colonization.

Twenty-four hours after inoculation, the bacteria started to invade the internal tissues of the roots. Confocal microscopy of different regions of cross-sections of maize roots inoculated with strain RAM4 showed colonization of the apoplast near the root surface (Figure 2). The bacterial population decreased progressively from the epidermis to the central cylinder, but fluorescent bacteria were clearly observed in the cortex, endodermis and xylem regions. This pattern of colonization suggests that $H$. seropedicae can rapidly penetrate the plant tissues and infect the xylem vessels.

The pattern of maize root colonization three days after inoculation showed a clear increase in internal colonization (Figure 2), with a higher number of strain RAM4 in the endodermis and the central cylinder. The bacteria were also dispersed in the intercellular spaces, mostly as isolated cells (Figure 2, arrow). This colonization pattern was observed in three independent inoculation experiments and was also observed in separate experiments involving $H$. seropedicae strains ZM152 and ZA95 (data not shown).

Our results suggest that $H$. seropedicae penetrates to the interior of maize roots by entering via cracks at the lateral root junctions. After entering, the bacteria rapidly colonize intercellular junctions and are distributed to the cortex, endoderm cells, and xylem vessels of maize root tissues.

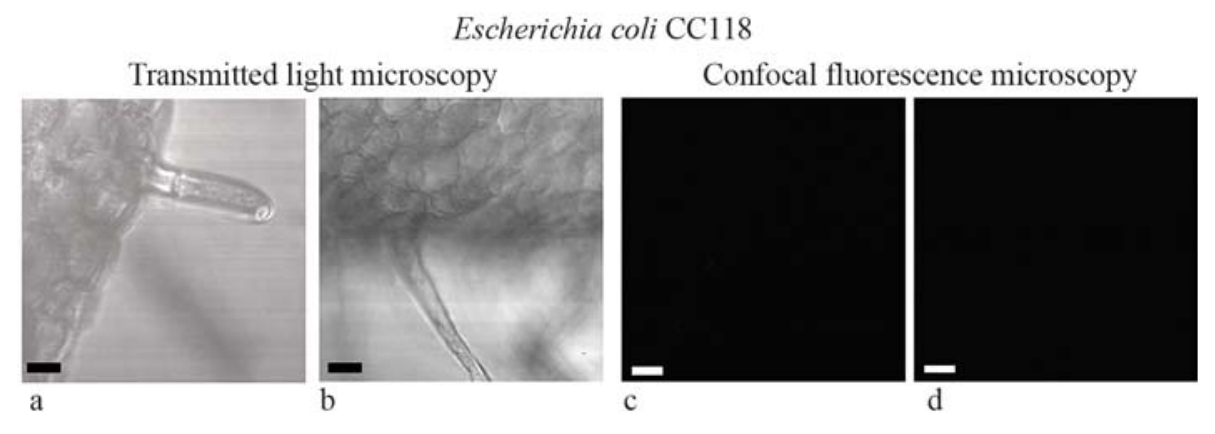

Herbaspirillum seropedicae RAM4
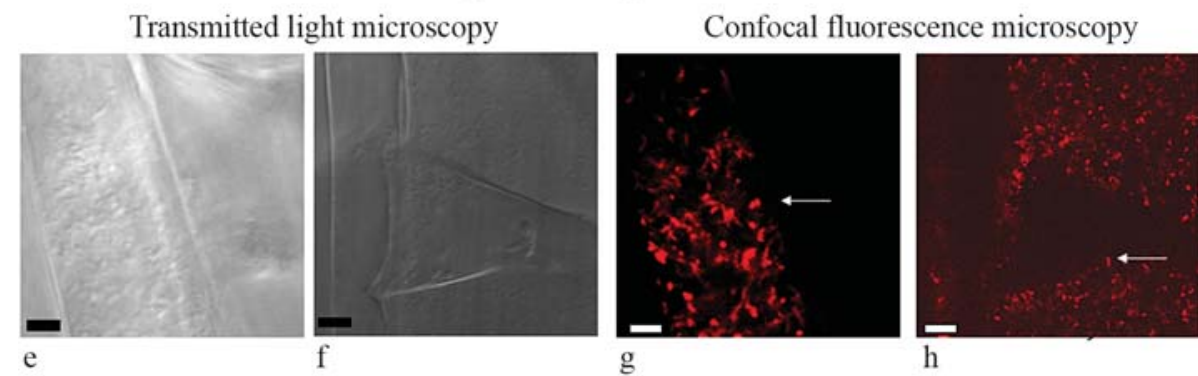

Figure 1 - Maize root tissue thirty minutes and one hour after inoculation with Herbaspirillum seropedicae strain RAM4 or E. coli CC118 (control), both expressing red fluorescent protein. Photomicrographs of a cross-section of maize root thirty minutes (a, c, e and g) and one hour (b, d, fand h) after inoculation with $E$. coli $\mathrm{CC} 118$ (upper panel) or H. seropedicae strain RAM4 (bottom panel). Left - transmitted light microscopy, righ - confocal fluorescence microscopy. Arrows show bacteria accumulating in the lateral root. After one hour clumps of bacteria can be seen at the lateral root junctions and spreading into the epidermis. Bars: $\mathrm{a}=15 \mu \mathrm{m} ; \mathrm{b}=50 \mu \mathrm{m}$. 
24 hours after inoculation

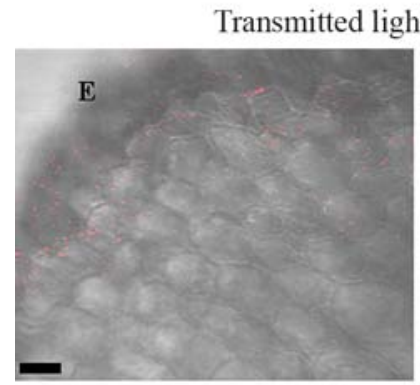

a

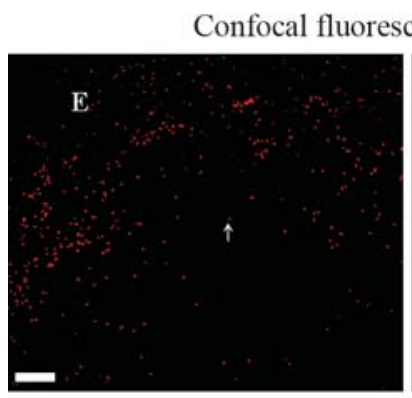

c

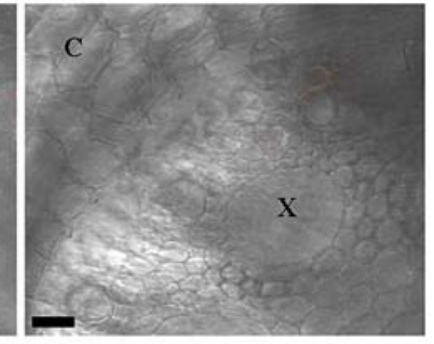

b

ence microscopy

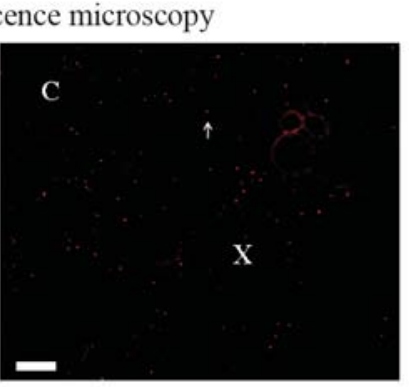

d
72 hours after inoculation

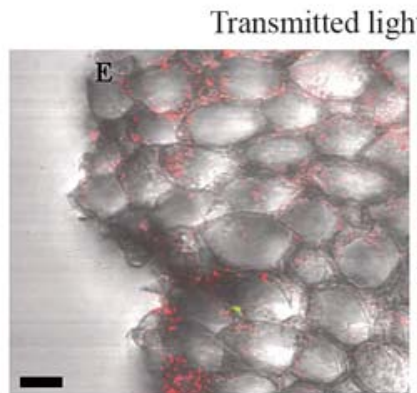

e

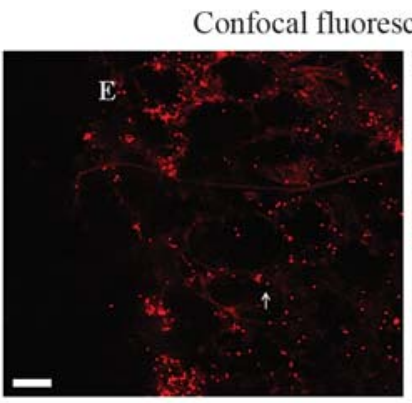

g

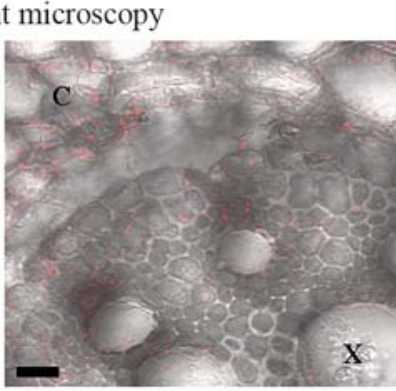

f

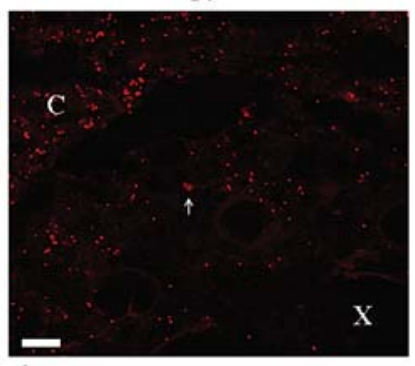

$\mathrm{h}$

Figure 2 - Transmitted light and confocal fluorescence microscopy of a cross-section of maize root 24 (a to d) and $72 \mathrm{~h}$ (e to h) after inoculation with Herbaspirillum seropedicae strain RAM4. The images were recorded in two different regions of the cross-section: the epidermis (a, c, e and g) and the central cylinder (b, d, f and h). Key: $\mathrm{E}=$ epidermis; $\mathrm{X}=$ xylem vessels; $\mathrm{C}=$ cortex. Arrows indicate the fluorescent bacteria. $\mathrm{Bars}=50 \mu \mathrm{m}$.

Accumulation of Herbaspirillum spp cells has previously been shown to occur at the lateral root emerging points two days after inoculation for rice (James et al., 2002), four days after inoculation for sugar cane (James and Olivares, 1998; Olivares and James, 2000) and five days after inoculation for rice, sorghum, maize and wheat (Roncato-Maccari et al., 2003).

The data from our study indicates that the $H$. seropedicae strain RAM4 colonization and invasion process is very rapid. Thirty minutes after maize root inoculation, we observed a high density of strain RAM4 at the lateral root junctions, which increased substantially after one hour. This finding agrees with studies that indicate that these parts of the roots are highly susceptible to disruption (Agarwhal and Sende, 1987). A similar pattern of root colonization by other diazotrophs has been reported for Azhorhizobium caulinodans, which also colonized lateral root cracks of Arabidopsis thaliana and Oryza sativa (Gough et al., 1997; Gopalaswamy et al., 2000), and Azoarcus sp. strain BH72 labeled with green fluorescent protein (GFP), which was found in high number in rice lateral roots (Egener et al., 1998). In addition, beta-glucuronidase staining (GUS) of rice roots has shown lateral root junction colonization by $H$. seropedicae strain Z67 (James et al., 2002). Recently, Liu et al., (2006) also reported accumulation of GFP-labeled Bacillus megaterium at the lateral roots cracks of maize and rice. It is possible that the bacteria secrete cell wall-degrading enzymes, such as cellulases and pectinases, at these susceptible root regions to facilitate entry.

As mentioned above, $24 \mathrm{~h}$ after the start of the experiment we found $H$. seropedicae strain RAM4 in all parts of the root tissues, with this internal distribution increasing further by the $72 \mathrm{~h}$ after inoculation. Roncato-Maccari et al., (2003), using normal microscopy of root sections, also found Herbaspirillum distributed throughout the roots of maize five days after inoculation. Our results show that by using bacteria labeled with red fluorescent protein it is possible to verify that only $24 \mathrm{~h}$ after inoculation the root, including the xylem, is completely colonized by the bacteria. Colonization of the vascular system of the plant allows the bacteria to distribute throughout the plant, indicating that invasion is a very rapid process, and occurs in the absence any visible defense response by the plant.

In our experiments, the presence of a large number of bacteria in the intercellular spaces was probably due to the fact that there is more space and a higher concentration of carbon source in the apoplast (Bennett and Lynch, 1981). The presence of the bacteria in the cortex, endoderm cells and xylem vessels indicate that these bacteria probably utilize plant nutrients and, in turn, can secrete metabolites that can be used by the plant (Grayston et al., 1997).

It is known that $H$. seropedicae has a low survival rate in sterile soils, suggesting that this organism is highly specialized in colonizing plants and supporting the efficient colonization pattern observed by us. However, it is impor- 
tant to note that our study was carried out under axenic culture in the absence of competing bacteria. The introduction of competition may substantially change the pattern observed, since fewer attachment points may be available, competing bacteria may secrete anti-bacterial substances and the plant may elaborate a defense against the mixed bacterial population. Other authors have reported infection and colonization of plant tissues by $H$. seropedicae using light and electron microscopy and the beta-glucuronidase gusA reporter gene (James and Olivares, 1998; James et al., 2002; Roncato-Maccari et al., 2003).

Our study indicates that the use of fluorescent marked proteins and confocal microscopy of fresh plant tissue has several advantages as an investigative tool in that it reduces procedural artifacts, allows very rapid (within minutes) detection and quantification of the bacteria and facilitates the design of competition experiments involving one or more competing pathogenic or non-pathogenic microorganisms. This combination of techniques is an important tool for furthering understanding of plant-microbe interactions.

\section{Acknowledgments}

This work was supported by the Brazilian agencies CAPES, CNPq, FINEP-MCT-PRONEX96, FUNPAR. The authors thank Roseli Prado and Julieta Pie for technical assistance and Michèle Crèvecoeur for suggestions.

\section{References}

Agarwhal S and Sende ST (1987) Tetrazolium reducing microorganisms inside the root of Brassica species. Curr Sci 56:187-188.

Assmus B, Hutzler P, Kirchhof G, Amann R, Lawrence JR and Hartmann A (1995) In situ localization of Azospirillum brasilense in the rhizosphere of wheat with fluorescently labeled, rRNA-targeted oligonucleotide probes and scanning confocal laser microscopy. Appl Environm Microbiol 61:1013-1019.

Baldani JI, Baldani VLD, Seldin L and Döbereiner J (1986a) Characterization of Herbaspirillum seropedicae gen. nov., sp. Nov., a root-associated nitrogen-fixing bacterium. Int J Syst Bacteriol 33:167-172.

Baldani VLD, Alvarez MAB, Baldani, JI and Döbereiner J (1986b) Establishment of inoculated Azospirillum spp. in the rhizosphere and in roots of field grown wheat and sorghum. Plant Soil 90:35-40.

Bennett RA and Lynch JM (1981) Bacterial growth and development in the rhizosphere of gnotobiotic cereal plants. J Gen Microbiol 125:95-102.

Cruz LM, Souza EM, Weber OB, Baldani JI, Dobereiner J and Pedrosa FO (2001) 16S ribosomal DNA characterization of nitrogen-fixing bacteria isolated from banana (Musa spp) and pineapple (Ananas comosus (L.) Merril). Appl Environ Microbiol 67:2375-2379.

Döbereiner J (1966) Azotobacter paspali sp. nov., uma bactéria fixadora de nitrogênio na rizosfera de Paspalum. Pesq Agrop Bras 1:357-365.
Egener T, Hurek T and Reinhold-Hurek B (1998) Use of green fluorescent protein to detect expression of nif genes of Azoarcus sp. BH72, a grass-associated diazotroph, on rice roots. Mol Plant Microbe Interact 11:71-75.

Egener T, Hurek T and Reinhold-Hurek B (1999) Endophytic expression of nif genes of Azoarcus sp. strain $\mathrm{BH} 72$ in rice roots. Mol Plant Microbe Interact 12:813-819.

Gopalaswamy G, Kannaiyan S, O'Callaghan KJ, Davey MR and Cocking EC (2000) The xylem of rice (Oryza sativa) is colonized by Azorhizobium caulinodans. Proc R Soc Lond Ser B 267:103-107.

Gough C, Vasse J, Galera C, Webster G, Cocking E and Denarie J (1997) Interactions between bacterial diazotrophs and non-legume dicots: Arabidopsis thaliana as a model plant. Plant Soil 194:23-130.

Grayston SJ, Vaughan D and Jones D (1997) Rhizosphere carbon flow in trees, in comparison with annual plants: The importance of root exudation and its impact on microbial activity and nutrient availability. Appl Soil Ecol 5:29-56.

James EK (2000) Nitrogen fixation in endophytic and associative symbiosis. Field Crops Res 65:197-209.

James EK and Olivares FL (1998) Infection and colonization of sugar cane and other graminaceous plants by endophytic diazotrophs. Crit Rev Plant Sci 17:77-119.

James EK, Gyaneswar P, Mathan N, Barraquio WL, Reddy PM, Iannetta PPM, Olivares FL and Ladha JK (2002) Infection and colonization of the rice seedlings by the plant growthpromoting bacterium Herbaspirillum seropedicae Z67. Mol Plant Microbe Interact 15:894-906.

Klassen G, Pedrosa FO, Souza EM, Funayama S and Rigo LU (1997) Effect of nitrogen compounds on nitrogenase activity in Herbaspirillum seropedicae strain SMR1. Can J Microbiol 43:841-846.

Liu X, Zhao H and Chen S (2006) Colonization of Maize and Rice plants by strain Bacillus megaterium C4. Curr Microbiol 52:186-190.

Lodewyckx C, Vangronsveld J, Porteous F, Moore ERB, Taghavi $\mathrm{S}$ and Van der Lelie D (2002) Endophytic bacteria and their potential applications. Crit Rev Plant Sci 6:583-606.

Matz MV, Fradkov AF, Labas YA, Savitsky AP, Zaraisky AG, Markelov ML, and Lukyanov SA (1999) Fluorescent proteins from nonbioluminescent Anthozoa species. Nat Biotechnol 17:969-973.

Olivares FL and James EK (2000) Endophytic establishment of diazotrophic bactéria in sugar cane plants. In: Pedrosa FO, Hungria M, Yates MG and Newton WE (eds) Nitrogen Fixation: From Molecules to Crop Producticity. Kluwer, Dordrecht, pp 413-414.

Pedrosa FO, Teixeira KRS, Machado IMP, Steffens MBR, Klassen G, Benelli EM, Machado HB, Funayama S, Rigo LU, Ishida ML, et al. (1997) Structural organization and regulation of the nif genes of Herbaspirillum seropedicae. Soil Biol Biochem 29:843-846.

Reiter B, Pfeifer U, Schwab H and Sessitsch A (2002) Response of endophytic bacterial communities in potato plants to infection with Erwinia carotovora subsp atroseptica. Appl Environ Microbiol 68:2261-2268.

Roncato-Maccari LDB, Ramos HJO, Pedrosa FO, Alquini Y, Chubatsu LS, Yates MG, Rigo LU, Steffens MBR and Souza EM (2003) Endophytic Herbaspirillum seropedicae 
expresses nif genes in gramineous plants. FEMS Microbiol Ecol 45:39-47.

Siciliano SD, Fortin N, Mihoc A, Wisse G, Labelle S, Beaumier D, Ouelette D, Roy R, Whyte LG, Banks MK, et al. (2001) Selection of specific endophytic bacterial genotypes by plants in response to soil contamination. Appl Environm Microbiol 67:2469-2475.
Tolker-Nielsen T, Brinch UC, Ragas PC, Andersen JB, Jacobsen CS and Molin S (2000) Development and dynamics of Pseudomonas sp. biofilms. J Bacteriol 182:6482-6489.

Associate Editor: Márcio de Castro Silva Filho

License information: This is an open-access article distributed under the terms of the Creative Commons Attribution License, which permits unrestricted use, distribution, and reproduction in any medium, provided the original work is properly cited. 